\title{
Determination of Moisture Levels, Protein and Water Absorption of Chicken Giblets
}

\section{-Author(s)}

\section{Scaratti D'}

Geremias R"

Franchin PR III

Scaratti GIV

Professor and researcher at Unoesc Videira - SC

" Professor and researcher at Unoesc Videira $-\mathrm{SC}$

III Researcher at Unoesc Videira - SC

Iv M. Sc. student in Chemical Engineering at UFSC

\section{Mail Address}

Corresponding author e-mail address Dirceu Scaratti

Rua Gênova, 50E - Apto 704

Presidente Médici - Chapecó - SC - Brazil

89801115

Phone: (5549) 99121181

E-mail: dirceu.scaratti@gmail.com

\section{EKeywords}

Chicken giblets, Chiller, Moisture, Protein, Water absorption.

\section{ABSTRACT}

This study aimed at evaluating the levels of moisture, protein, water to protein ratio, and water absorption during chilling of chicken giblets (heart, liver, and gizzard) to set legal limits of water absorption during this process. The survey was conducted in the southern Brazil, the largest broiler-producing region of this country. Giblets (heart, liver, and gizzard) were collected fresh from the processing line after evisceration and at the exit of the chiller after the immersion process from two processing plants. One of the plants (PP1) processes small chickens $(1,100 \mathrm{~g}$ live weight) and PP2 processes chickens with $2,800 \mathrm{~g}$ live weight. In total, 448 samples were collected. Laboratory tests were performed in duplicate for each parameter measured. The results show that moisture levels of fresh giblets were higher in the gizzard, followed by the liver and the heart, whereas in chilled giblets, the gizzard still maintained the highest moisture level, but was followed by the heart and then the liver. Both in fresh and chilled samples, the liver presented the highest protein content, followed by the gizzard and the heart. Water to protein ratios were higher in chilled than in fresh samples, and was highest in the heart, followed by the gizzard and the liver. After immersion in the chiller, the heart presented the highest water absorption rate $(6.59 \%)$, which was significantly higher compared with those of the liver (4.16\%) and the gizzard (4.51\%). Considering that the water absorption rates obtained both in fresh and chilled chicken giblets were below $8.00 \%$, the following upper limits of water absorption are suggested for chicken giblet processing in Brazil: 7.0\% for the heart, and $5.0 \%$ for the gizzard and the liver.

\section{INTRODUCTION}

Consumers' complaints on allegedly high levels of water in frozen chicken carcasses and parts have received attention of the media. Processing plants, the government, and consumers have been involved in this issue, because the consumers may be deceived, paying for water instead of protein. In Brazil, water absorption rates of whole carcasses and meat parts are regulated (Normative Instruction $N^{\circ}$ 032/2010 of the Ministry of Agriculture - MAPA). However, giblets are not included in these regulations, pointing out the need of studies to determine such levels. Moreover, chicken giblets must also comply with health consumers' rights demands and required physiological characteristics.

Adequate chilling is essential for the preservation of carcass quality. According to Dinçer (1997), preservation is the most important technological step in food processing, influencing the shelf life of the products by maintaining their microbiological, physicochemical, and sensory properties. Pre-chilling carcasses by immersion in cold water is not the only method of chilling, but it is the most frequently used in Brazilian chicken processing plants. Chilling using cold air is commonly 
used in refrigerated pork and beef production, but it is seldom applied in chicken processing, particularly due to its high cost.

Chicken carcasses absorb water when submitted to pre-chilling by immersion in water, usually in a coldwater tank called chiller. The excessive absorption of water by chicken carcasses during pre-chilling is the subject of constant debate among chicken meat producers, consumers, and the authorities responsible for its control (Gruda \& Potolski, 1986). Excessive water levels in chicken carcasses do not necessarily result from water injection into the product, rather to inadequate setting of the technological variables that influence the pre-chilling process. Chicken carcasses absorb water during pre-chilling by water immersion mainly as a consequence of chiller water temperature, length of stay in the system, carcass abdominal cut, and air injection system (bubbling), according to Katz \& Dawson (1964).

The logistics of storage and distribution and/or inadequate food handling by consumers may also compromise the quality of chicken meat because they affect meat functional properties, including waterholding capacity, which is an important property related to the hydrostatic stability of proteins (Malinverni, 2004).

During chilling, chicken carcasses are immersed in two iced water bath systems (pre-chiller and chiller), when water is absorbed. After chilling, carcasses need to be hanged to eliminate the water absorbed during immersion in the chiller tanks. Chilling parameters are regulated by Ordinance $N^{\circ} 210 / 1998$ of the Brazilian Ministry of Agriculture (MAPA; Martins et al., 2007). Maximum water uptake during pre-chilling should be no more than $8 \%$ (Sarcinelli et al., 2007), while there are specific moisture and protein levels to be observed for different parts of the carcass (Normative Instruction $N^{\circ}$ 032/2010 of the Ministry of Agriculture - MAPA).

This study aimed at evaluating water, protein, and water absorption rates of chicken giblets (heart, liver, and gizzard) during chilling with the objective of establishing water absorption limits during this process and contributing for the discussion on the establishment of legal requirements in Brazil.

\section{MATERIAL AND METHODS}

The processing plants selected for the study (PP1 and PP2), are located in the mid-west of the state of Santa Catarina, Brazil, and process around 300,000 chickens daily. The PP1 processes broilers with approximately $1,100 \mathrm{~g}$ live weight and PP2 processes $2,800 \mathrm{~g}$ broilers.

Considering the lack of specific legislation establishing water absorption limits in chicken giblets, a pilot study was conducted to define and to validate sampling. The analyses were performed at the physicochemical laboratories owned by the processing plants, located in the cities of Capinzal and Videira, both in the state of Santa Catarina, Brazil.

In the pilot study, ten samples of chicken heart, liver, and gizzard were collected fresh, immediately after the evisceration line and at the exit of the chiller. The results of the analyses of water and protein level, water to protein ratio, and water absorption rates were used to determine the sampling plan. One hundred and twenty samples were collected for the pilot test and other 328 samples for the main study, at both processing plants. Samples were randomly collected in the processing line immediately after evisceration and at the exit of the chiller. Samples were collected on August 17-20, 2010 for the pilot study, and on September 01-15, 2010 for the main study.

A minimum number of each giblet was collected to obtain pooled samples of $300 \mathrm{~g}$ of heart, $400 \mathrm{~g}$ of gizzard, and $500 \mathrm{~g}$ of liver. The samples were placed in polystyrene boxes and immediately submitted to laboratory of the respective processing plant for analyses. Giblet pools were ground in food processor (Robot Coupe Blixer® 3, Germany) and analyzed in duplicate for water and protein levels according to the method described in Normative Instruction N²0/1999 of MAPA. The water to protein ratio of both the fresh and chilled samples was calculated as:

$\frac{W}{p}=\left[\frac{W}{p}\right]$, where:

$\bar{W}=$ average water percentage of the sample

$\bar{P}=$ average protein percentage of the sample

$W / P=$ water to protein ratio

Water absorption rate of the fresh samples after pre-chilling was calculated as:

$W A C=\frac{W \text { Chilled }-W \text { Fresh }}{W \text { Fresh }} \times 100$, where:

$\bar{W}=$ average water percentage of the sample

WAC $=$ water absorption during chilling 


\section{Sample size determination}

The estimation of the population average at 95\% significance level was used to calculate sample size.

$$
n=\left[\frac{Z x \sigma}{E}\right]^{2} \text { where: }
$$

\section{$Z(95 \%)=1.96$}

$\sigma=$ pilot standard deviation mean (60 samples $x$ duplicate) $=0.306$

Standard error of the total pilot sample $=0.110$

$$
n=\left[\frac{1.96 \times 0.306}{0.11}\right]^{2} \cong 29
$$

Considering the calculated sample size, at least additional 19 sample collections were proposed. Figure 1 illustrates the sample collection flow and the experimental design.

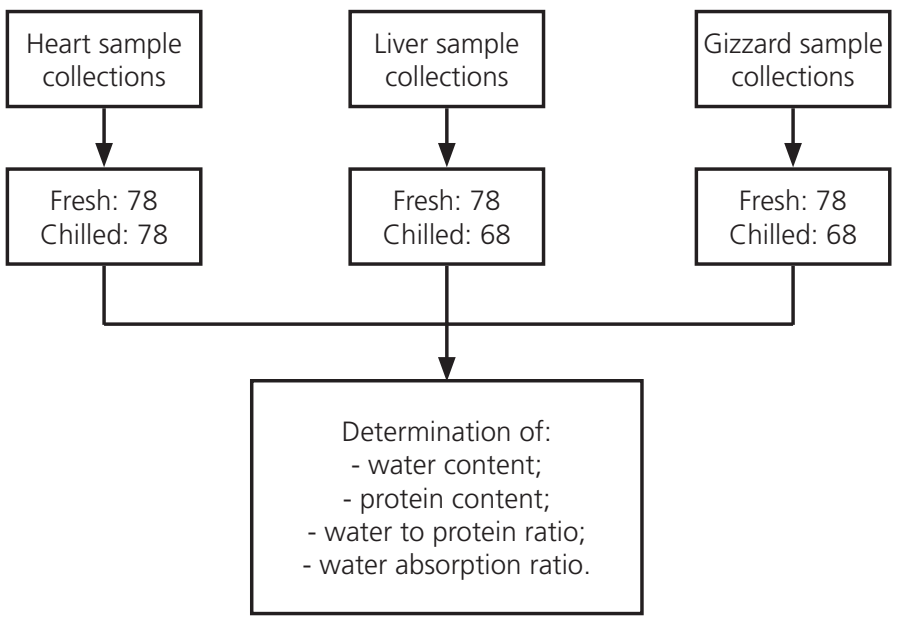

Figure 01 - Flowchart and delineation of representative samples and collections.

Data were analyzed by the software program Statistic 10.0. The data were submitted to analysis of variance (ANOVA) at $95 \%$ probability level to determine if differences between fresh and chilled giblets were significant. Water absorption values were also compared with the test to verify possible differences between giblets obtained from chilled.

\section{RESULTS AND DISCUSSION}

The experimental results were grouped per type of giblet (heart, liver, and gizzard) and sampling site (fresh giblets collected immediately after evisceration and chilled giblets collected at the exit of the chiller). The minimum sample size required to validate the results (equation 3) was determined at 95\% probability level. Table 1 shows average moisture and protein levels, water to protein ratio, and water absorption results (equation 2), according to giblet type and collection site, considering $95 \%$ probability level.

Average moisture content was highest in the gizzard, both in fresh (81.42\%) and chilled (84.44\%) samples. The fresh heart presented the lowest moisture level (75.45\%), followed by the chilled liver $(80.29 \%)$. The lowest variability (standard deviation) was obtained both in fresh (1.329) and chilled (0.912) livers, whereas the highest variability was detected both in fresh and chilled gizzards. When comparing the moisture content between fresh and chilled giblets, only the liver presented significant differences $(p=0.0032)$, differently from the heart $(p=0.3291)$ and from the gizzard $(p=0.1750)$.

Average protein content was highest in the fresh $(19.73 \%)$ and chilled (17.28\%) liver, whereas the lowest protein content was observed in the fresh heart $(13.57 \%)$ and the fresh gizzard $(16.87 \%)$. The chilled heart presented $11.73 \%$ protein content, and the chilled gizzard, $14.87 \%$. Both the fresh and chilled gizzards presented the highest variability in protein content variability. Protein content was only statistically different between fresh and chilled heart $(p=0.0021)$, while no differences were detected in the liver $(p=0.3106)$ or in the gizzard $(p=0.4174)$.

Average water to protein ratio, calculated according to Equation 1, was highest in the chilled heart (6.78), followed by the chilled gizzard (5.70), the fresh heart (5.56), the fresh gizzard (4.84), the chilled liver (4.65), and the fresh liver (3.90). The difference in water to protein ratio between fresh and chilled samples was

Table 01 - Moisture and protein levels, moisture to protein ratio, and water absorption rate (mean \pm standard deviation)

\begin{tabular}{|c|c|c|c|c|c|c|c|c|c|c|}
\hline \multirow{2}{*}{ Giblets } & \multicolumn{3}{|c|}{$\overline{\boldsymbol{W}}(\%)$} & \multicolumn{3}{|c|}{$\overline{\boldsymbol{P}}_{(\%)}$} & \multicolumn{3}{|c|}{$\overline{\boldsymbol{W} / \boldsymbol{P}}_{(\%)}$} & \multirow{2}{*}{$\overline{W A C}_{(\%)}$} \\
\hline & Fresh & Chilled & P-value & Fresh & Chilled & $\mathrm{p}$-value & Fresh & Chilled & $p$-value & \\
\hline Heart & $75.45 \pm 1.361$ & $80.39 \pm 1.297$ & 0.3291 & $13.57 \pm 0.515$ & $11.73 \pm 0.587$ & 0.0021 & $5.56 \pm 0.240$ & $6.78 \pm 0.531$ & 0.1808 & $6.59 \pm 2.45$ \\
\hline Liver & $77.20 \pm 1.329$ & $80.29 \pm 0.912$ & 0.0032 & $19.73 \pm 0.446$ & $17.28 \pm 0.427$ & 0.3106 & $3.90 \pm 0.127$ & $4.65 \pm 0.170$ & 0.0446 & $4.16 \pm 1.93$ \\
\hline Gizzard & $81.42 \pm 1.930$ & $84.44 \pm 2.010$ & 0.1750 & $16.87 \pm 0.733$ & $14.87 \pm 0.907$ & 0.4174 & $4.84 \pm 0.245$ & $5.70 \pm 0.412$ & 0.1460 & $4.51 \pm 2.35$ \\
\hline
\end{tabular}
of fresh and chilled chicken giblets.

$\bar{W}(\%)$ - average water percentage, $\bar{P}(\%)$ - average protein percentage, $\overline{W / P}$ - water to protein ratio, $\overline{W A C}(\%)$ - water absorption during chilling 
only significant for the liver $(p=0.0446)$, but not for the heart $(p=0.1808)$ or the gizzard $(p=0.1460)$. The higher water to protein ratio detected in the heart may be due to the fact that it is a hollow muscle and its cavities allows water accumulation while immersed in the chiller tank (Romer \& Parsons, 1985; Pough et al., 2003; Hildebrand, 2006).

The rates of water absorption of the fresh giblets after immersion in the chiller were calculated (Equation 2) as $6.59 \%$ for the heart, $4.16 \%$ for the liver, and $4.51 \%$ for the gizzard. These values are consistent with the findings of Scaratti et. al. (2010), who obtained water absorption rates of $7.19 \%, 4.85 \%$, and $4.75 \%$ in the heart, gizzard, and liver after chilling, respectively. The lower water absorption rate observed in the gizzard and the liver compared with the heart may be explained by the prevention of water absorption by the firm submucosa and abrasion-resistant mucosa of the gizzard EMBRAPA-CNPSA, 1998), and by the encapsulation of the liver by a thin layer of connective tissue (Bacha \& Bacha 2003).

\section{CONCLUSIONS}

The results of the comparison between fresh and chilled chicken giblets (liver, heart, and gizzard) that chilling increased the water content of the liver, the protein content of the heart, and the water to protein ratio of the liver, whereas the gizzard was not affected by chilling. The following upper limits of water absorption are suggested for chicken giblet processing in Brazil: $7.0 \%$ for the heart, and $5.0 \%$ for both the gizzard and the liver.

\section{REFERENCES}

Bacha WJ, Bacha LM. Atlas colorido de histologia veterinária. 2nd ed. São Paulo: ROCA; 2003.
Brasil. Instrução Normativa n 032, de 03 de dezembro de 2010. Parâmetros para avaliação do teor total de água contida nos cortes de frangos, resfriados e congelados. Diário Oficial da União, Brasília, DF, 07 de dezembro 2010.

Brasil. Instrução Normativa $n^{\circ}$ 20, de 21 de julho de 1999. Métodos analíticos físico-químicos para controle de produtos cárneos e seus ingredientes. Diário Oficial da União, Brasília, DF, 27 de setembro de 1999

Brasil. Portaria n² 210, de 10 de novembro de 1998. Regulamento técnico da inspeção tecnológica e higiênico-sanitária de carne de aves. Diário Oficial da União, Brasília, DF, 26 de novembro de 1998.

Dinçer I. Heat transfer in food cooling applications. Washington: Taylor \& Francis; 1997.

EMBRAPA-CNPSA. Anais do Simpósio Sobre Granulometria de ingredientes e rações para suínos e aves; 1998 Out 01; Concórdia, SC; 1998.

Gruda Z, Postolski J. Tecnología de la refrigeración de los alimentos. Zaragoza: Editorial Acribia; 1986.

Hildebrand M. Análise da estrutura dos vertebrados. 2nd ed. São Paulo: Atheneu; 2006.

Katz M, Dawson LE. Water absorption and retention by cut up broiler parts chilled in polyphosphate solution. Poultry Science 1964;43;1541-1546.

Malinverni C. Terceirização como estratégia: o desafio do mercado. Revista Tecnologística 2004;103:56.

Martins TD, Klassen T, Cardozo Filho L, Silva EA. Modelagem da temperatura e da retenção de água no processo de resfriamento de carcaças de frango. Anais do $7^{\circ}$ Congresso Brasileiro de Engenharia Química em Iniciação Científica; 2007 Jul 29; São Carlos: UFSCAR; 2007 [cited 2011 Jul 09]. Available from: http://www.ufscar.br/cobeqic07/pdf/oral/i3.pdf.

Pough FN, Heiser JB, McFarland WNA. A vida dos vertebrados. $3^{a}$ ed. São Paulo: Atheneu; 2003.

Romer AS, Parsons TS. Anatomia comparada dos vertebrados. São Paulo: Atheneu; 1985.

Sarcinelli MF, Venturini KS, Silva LC. Abate de Aves [boletim técnico]. Alegre: Universidade Federal do Espírito Santo; 2011 [cited 2011 Aug 09]. Available from: http://www.agais.com/telomc/b00607_ abate randodecorte.pdf.

Scaratti D, Geremias R, Franchin PR, Scaratti G. Avaliação dos níveis de umidade e proteína em miúdos oriundos de frangos abatidos com peso de $1.100 \mathrm{~g}$ e $2.800 \mathrm{~g}$. Evidência 2010;10(1/2): 17-26. 